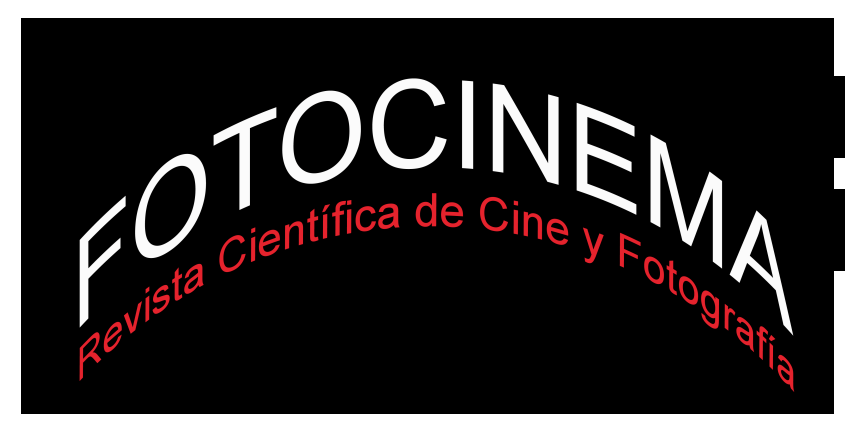

\title{
EL LENGUAJE DE ANIMACIÓN COMO HERRAMIENTA POÉTICA PARA MITIFICAR LA HISTORIA DE EVA PERÓN
}

\section{THE POETIC LANGUAGE ANIMATION AS TOOL TO MYSTIFY HISTORY EVA PERÓN}

\author{
Jimena C. Trombettta \\ Universidad de Buenos Aires / CONICET, Argentina \\ jimenacecilia83@gmail.com
}

\section{Resumen:}

La imagen de Eva Perón fue visitada en diferentes épocas por diversos lenguajes artísticos, el cinematográfico en sus dos versiones ficción $\mathrm{y}$ documental, el plástico, el teatral y el literario. En la contemporaneidad dentro del lenguaje cinematográfico se dio espacio para representar la imagen de Eva desde el cine de animación. Dicho film se trata de Eva de la Argentina (2011) de María Seoane, del cual nos interesa analizar la interacción entre los registros de animación y de documental. Asimismo ambos registros componen un punto de vista sobre la historia y conforman una memoria que nos hará pensar sobre la creación del personaje desde la animación. A su vez en el relato se incorporan como recurso narrativo el entrecruzamiento con la literatura. Así el cuento de Rodolfo Walsh, Esa mujer será otra creación que estimula la mitificación de la figura de Eva Perón. De este modo, Rodolfo Walsh como personaje narra los hechos desde 1966. Este cruce literario habilita la confluencia de tres tiempos, la década peronista, el onganiato que vivió Walsh y la interpretación que da María Seoane desde la época actual.

\begin{abstract}
:
The image of Eva Peron was visited at different times by different artistic languages, the film in two versions fiction and documentary, plastic, theatrical and literary. In the contemporary cinematic language within the space it was given to represent the image of Eva from the animated film. This film is Eva de la Argentina (2011) by Maria Seoane, which we want to analyze the interaction between records of animation and documentary. Both records also make a point of view on the history and make a memory that will make us think about creating the character from animation. In turn in the story as a narrative device incorporated interbreeding with literature. So the story of Rodolfo Walsh, Esa mujer will be another creation that stimulates the mystification of the figure of Eva Perón. Thus, Rodolfo Walsh as a character recounts the events since 1966 . This enables literary crossing the confluence of three times, the Peronist decade, onganiato Walsh lived and the interpretation given Maria Seoane from the present time.
\end{abstract}

Palabras clave: cine de animación; cine documental; memoria; historia; Eva Perón

Keywords: Animation Film; Documentary Film; Memory; History; Eva Perón 


\section{Introducción}

Eva Perón se conformó a lo largo de su carrera política -desde 1945 hasta el día de su muerte el 26 de julio de 1952- como una figura transgresora y controversial. La constitución de su imagen como mito comenzó con su vida política y se afianzó con el embalsamamiento de su cadáver. A partir de allí se crearon numerosas interpretaciones dentro del cine, del teatro y de la literatura en Argentina y en el extranjero. Entre los materiales literarios que se conocen se encuentra el cuento de Rodolfo Walsh, que narra la entrevista entre el periodista y el coronel Moori Koenig. Este cuento de 1966 se circunscribe a una álgida época de Argentina. Gobernaba Onganía, el peronismo continuaba proscripto y el cadáver de Eva seguía desaparecido para el pueblo, aunque enterrado bajo otro nombre en un cementerio de Milán, Italia. Este marco histórico fue considerado por la película Eva de la argentina (María Seoane, 2011).

En este caso, la imagen de Eva Perón fue llevada a la escena cinematográfica desde la conjunción del cine de animación y del documental. El cuerpo del artículo tendrá como meta desarrollar el análisis de caso sobre Eva de la Argentina. Sin embargo, antes de analizar el tema específico comprenderemos las problemáticas entre ambos lenguajes. Lo primero que nos interesa replantear es la tensión entre la ficción y el documental, lo segundo es la constitución de la memoria y la utilización de la imagen de archivo, lo tercero es pensar el concepto de historia, el concepto de lo real y el concepto de mito.

Para establecer lazos entre estos términos trabajaremos con diferentes autores. Respecto del concepto de memoria aplicado al cine documental visitamos los materiales de Gustavo Aprea y Pablo Piedras. Para pensar la idea de historia nos basamos en el análisis de Hayden White. En cuanto a lo real en el documental es Adrián Cangi el que nos invita a pensar la problemática. A su vez tendremos en cuenta las categorizaciones que propone Bill Nicholls sobre el documental. El concepto de mito lo utilizaremos desde una amplia perspectiva como la de Roland Barthes. También consideramos pertinente incluir el artículo de Sara Álvarez Sarrat que explica las características del cine de animación como un 
medio impuro, o la acepción sobre la animación de Iuri Lotman quién lo considera una representación de la representación. A su vez como nos interesa observar qué tipo de heroína construye esta animación documentada creemos pertinente utilizar los conceptos sobre héroe propuestos por Christopher Vogler.

Nos parece válido considerar estos puntos teóricos ya que sostenemos que la figura de Eva Perón llevada a escena mediante el cine de animación genera una tensión adicional entre la historia, la memoria y el documental. Desde nuestro punto de vista, dicha tensión potencia la función poética de la historia por medio de la ficción. Por este motivo genera un corrimiento del referente aún mayor que el desplazamiento que podría generar un documental sin animación. Esto da por resultado la conformación de un personaje histórico que acude con mayor ahínco a sus mitos previos en tanto que de por sí se mitifica por las características del dispositivo.

\section{Breve desarrollo sobre las tensiones entre memoria, historia, documental y animación}

La primera tensión se da entre la historia, el documental y la conformación de una memoria. Gustavo Aprea señala que "la historia se presenta como una instancia crítica frente al pasado y la memoria tiende a interpretarlo con las categorías y desde el punto de vista del presente.” (2015, 37). A su vez retoma a Maurice Halbwachs y separa entre la memoria personal y la memoria colectiva, siendo la segunda más amplia que la primera, pero menos densa y continua. En el film de María Seoane son articuladas ambas memorias mediante la animación y el documental. Por su parte, y para generar una relación entre el documental y la historia, Pablo Piedras señala que el cine documental ha mantenido desde sus inicios una estrecha vinculación con la historiografía, dado que sus representaciones están dirigidas a postular algo sobre el mundo histórico. Este autor establece una relación con Hayden White, que como bien marca, propone su concepto de historiofotía, es decir la representación de la historia y nuestro pensamiento acerca de ella en imágenes visuales y discurso fílmico (Piedras, 2014, 149). El punto fundamental es que este modo cinematográfico de realizar 
un relato histórico implica una función poética -diría Hayden White- que establece una coherencia y una decisión autoral en el relato construido más allá de los hechos que lo validan. Esta función poética se encuentra por fuera de la dinámica que se establece entre la memoria individual de cada espectador y la memoria colectiva. En el primer caso fundada en la posibilidad de que haya vivido alguno de los hechos. En el segundo fundada en un sinfín de elementos históricos, de archivos y de experiencias personales: todas prácticas que no huyen de los imaginarios que las rodean. Ahora bien, la propuesta del caso que analizaremos no se circunscribe a una mera práctica documental sino que utiliza dicha práctica para inscribirla en un dispositivo que propicia la ficción: el cine de animación.

El dibujo mantiene en su esencia su gran poder de comunicación, de aprehensión de cuanto nos rodea, conformando un medio de expresión directa y rotunda de pensamientos, ideas o emociones. Es la equivalencia entre el dibujo y el pensamiento, tal y como aseveraba Bruce Nauman. Línea, trazo, gesto, contorno, forman parte de un vocabulario percibido mediante el recorrido de la mirada, que nos habla de la expresión personal enfrentada al método colectivo (Álvarez Sarrat, 2011, 47).

En este caso, la función poética salta a los ojos del espectador mediante los dibujos de aquellos personajes históricos que apuntan a particularidades que los caracterizan. Es ese contorno, ese gesto animado, ese trazo que se acerca a la iconografía del registro histórico, y a su vez genera un plus ficcional que lo aleja de la idea de la historia como disciplina y lo acerca a la idea de la memoria. Seoane con su animación documentada (un oxímoron) utiliza la historia en función de la memoria tanto colectiva como personal (de dos personajes: Rodolfo Walsh y Eva Perón), usa el documental con sus imágenes de archivo en función de la animación. Siempre destacando la función poética de la disciplina histórica y de la memoria, en tanto que el pasaje de ambas al lenguaje cinematográfico, desde nuestro punto de vista, se conforma también a través de dicha función. Desde este lugar el uso de la memoria y la historia aplicada al cine dan paso a crear mitos alrededor de las figuras de una manera más evidente. No sólo mitifican los personajes históricos por la amplia definición de 
mito que propone Barthes ${ }^{1}$, sino que la función poética se instala para gobernar la imagen de aquellos. Tal como sostiene Bordwell "la animación proporciona un control absoluto sobre la puesta en escena" (1993, 417). El dibujo alegoriza de por sí, por su propia característica compositiva, aún cuando narre un elemento basado en lo real. Aspecto curioso se da en el caso particular que vamos a analizar, ya que el personaje que recuerda, lo hace desde su propia construcción netamente poética: el cuento. Así, Rodolfo Walsh como narrador principal del film de María Seoane viene a cuestionar el carácter de realidad, incluso de los materiales de archivo, para convertirlos en pura interpretación o para transformar esa historia en un espacio poético, sobre todo porque el personaje es de animación. Por su parte, los fragmentos documentales vienen a testimoniar lo real como trauma, como forma incompleta de lo real en su representación (Cangi, 2007, 47). El rostro y el gesto de Eva son portadores del trauma político de su época, e interpelan el trauma político de la contemporaneidad del film.

Estas disquisiciones teóricas nos impulsan a preguntar, porqué en la historia actual es necesario realizar una Eva animada. Eva de la argentina de María Seoane narra la vida de Eva Perón a través de la animación. Esa decisión estética cuestiona e innova el modo de relatar un período histórico. Por esto surge la pregunta sobre cómo se postula lo real dentro de esa narrativa de animación y cómo desde allí se utilizan las imágenes de archivo; que también son esgrimidas para significar la mirada política del film. Es preciso comprender que dicho documental animado fue compuesto en una época histórica de la Argentina en que estaba en boga el revisionismo histórico. Éste trajo aparejado repensar las políticas peronistas y con ellas un retorno a analizar las imágenes de Perón y Eva Perón.

\footnotetext{
${ }^{1}$ Para Roland Barthes el mito se compone por dos cadenas semiológicas donde la segunda se desplaza de la primera en tanto que su significado se encuentra por fuera del signo de la primera. Esto constituye un nuevo signo que compone un concepto mítico. "el mito es un sistema doble, en él se produce una suerte de ubicuidad: un sentido. Para conservar una metáfora espacial cuyo carácter aproximativo ya he señalado, diría que la significación del mito está constituida por una especie de torniquete incesante que alterna el sentido del significante y su forma, un lenguaje-objeto y un meta-lenguaje, una conciencia puramente imaginante" (1980, 215).
} 
Con la finalidad de trabajar las imágenes de archivo incorporadas en Eva de la Argentina, y de observar las recreaciones que de ellas se realizan mediante la animación y el relato del narrador ficcional Rodolfo Walsh tendremos en cuenta como mencionamos la problemática de la memoria, la conformación del personaje dentro del material documental y la recreación de la figura histórica de Eva Perón a través de los dibujos de Francisco Solano López.

La decisión estética del film se ampara en la re-significación de las imágenes y en la reproducción de los mitos que circundan, aún hoy sobre la figura de Eva Perón. De este modo, el film de Seoane recupera el tono melodramático de la relación entre Perón y Evita, para derivar ese amor al pueblo y a la historia misma que narra el personaje Walsh en el filme.

Bill Nicholls postula una pregunta analizando los documentales de modalidad reflexiva específicamente, con la cuál pone sobre el tapete la complejidad de lo real:

¿Cómo puede el espectador tomar conciencia de esta problemática de modo que ningún mito sobre la capacidad de conocimiento del mundo, sobre el poder del logos, ninguna represión de lo invisible y de lo que no se puede representar oculte la magnitud de «lo que sabe todo realizador»: que toda representación, por muy imbuida que esté de significado documental, sigue siendo una fabricación? (Nicholls, 1997, 94).

Esta pregunta nos hace pensar que el trabajo de Seoane se permite la animación y la incorporación del registro documental, exactamente por tener conciencia de que se trata de una construcción sobre la imagen de Eva Perón. Lo que nos interesa destacar es cómo se unen ambos registros en determinadas escenas, mientras que en otros se separan manteniendo su propia característica de ficción animada y de documental.

Estas diferencias de base marcan dos caminos semióticos que alimentan la encrucijada. Mientras el cine fotográfico se presenta como un signo icónico indicial, en virtud de las relaciones de semejanza y contigüidad física con aquello que representa; la animación, cualquiera sea su técnica, se articula en base a símbolos icónicos, en tanto que las representaciones visuales están 
basadas en la similitud y la convención de uso en relación con aquello que representan. Así coincidimos con Pamela Gionco en que la animación ha contribuido a construir los personajes de la serie histórica incorporando una dimensión simbólica que "el registro de base fotográfica no puede aportar" (2013, 0760).

A su vez, tendremos en cuenta que desde la semiótica propuesta por Iuri Lotman, la animación provocaría una representación de la representación, es decir un signo de signo (Lotman, 2000). En este sentido se propicia una conciencia de la distancia propuesta por Seoane, en tanto que la elección estética es en función de dar cuenta de ese corrimiento del referente.

La animación, en estos casos, también hace evidente el hecho mismo que el documental como tal, no es una "ventana al mundo" o la cámara "una mosca en la pared", sino justamente, un artificio, un armado, realizado con un fin que es el de convencer, hacerle llegar a ese espectador una "idea", una "mirada", sobre ese mundo. (Pinotti, 2015, 156).

La práctica documental dentro de Eva de la Argentina repasa las imágenes de Eva Perón incluyendo no sólo material fílmico y fotográfico, sino también sonoro. Así, la película retoma los discursos y la voz de Eva Perón como una manera de reponer esa cuota de realidad que se pierde en algunos momentos de ficción, donde la animación permite el registro de lo alegórico y lo simbólico. Esa realidad documental también hace pie en los registros audiovisuales extraídos del Archivo General de la Nación con las imágenes del pueblo y sus voces, algo que refleja el impacto social y político de la figura de Evita. Las imágenes seleccionadas se dividen esencialmente en tres: aquellas que reflejan su desempeño político (recorrido por Europa, visita al Papa Pío XII, discursos en la Plaza de Mayo y el Cabildo Abierto), su carrera de actriz (concentradas estas imágenes en las tapas y contenidos de revistas como Radiolandia, Antena, y en la película La cabalgata del circo, Mario Soficci, 1945), su relación privada con Juan Domingo Perón (esta última basada en los registros periodísticos en los que se construye una cotidianidad romántica para la prensa). 
Todas estas imágenes se postulan como testimonios que acompañan la animación. Así, en momentos específicos pueden funcionar como un sumario de imágenes testimoniales que se resignifican a partir del recuerdo de Eva Perón/personaje animado. Esto acontece con la escena en la que Eva cansada y ya enterada de su enfermedad, se desvanece sobre el sillón y recuerda su regreso a Buenos Aires luego de su viaje a Europa, o los diferentes cócteles y actividades junto a Perón. Esta escena incorpora varios elementos donde la función de las pinceladas de documental toman impulso para reforzar la animación que, en ese momento, se dispone a narrar la historia de amor entre ellos dos, mezclando los elementos políticos con el melodrama, en tanto que la balada que suena es la que climatiza la ficción.

Otra escena que utiliza el material de archivo como herramienta de verosimilitud es aquella en la que se ve a Eva/personaje animado sentada en el escritorio leyendo las cartas enviadas a la Fundación. Junto a esa acción, la imagen animada incorpora por detrás un recorrido de planos de niños y de trabajadores recibiendo los materiales solicitados. El rostro de Eva y el espacio minimalista que se reproduce en el dibujo le quitan un espacio-tiempo específico, en tanto que lo importante es observar los gestos del personaje. De este modo, sostenemos junto a Cangi que:

La expresión de un rostro y su significación no tienen ninguna relación o enlace con el espacio. El rostro no es un objeto parcial ni un complejo metonímico, sino un dominio de cualidades y potencias, es decir, de afecciones que pueden ser expresadas por un semblante, un equivalente de este, o actualizadas en un estado de cosas. (Cangi, 2007, 38).

Esto permite comprender el funcionamiento de la animación dentro del film y en relación al documental. Si lo documental indica la veracidad de los testimonios fotográficos y fílmicos, la animación plantea niveles simbólicos y alegóricos. Así es como el rostro, el gesto, el dibujo con su vestuario y el peinado de Eva reflejan la segunda etapa de su carrera política, aquella en donde el traje sastre y el rodete eran los característicos, teniendo en cuenta que no siempre se narra ese tiempo específico. De este modo, se simbolizan mediante el dibujo, dos tipos de Eva: la vinculada con el trabajador dentro de su período de vida y, 
también, aquella con el pelo suelto al viento, que se vincula con la imagen retomada por la militancia en la década del '70. Mientras que una responde a la narrativa de la época que narra Walsh, la otra refiere a la propia época del personaje Walsh, lo que implica una relectura establecida a partir de otro personaje animado, como lo es el del propio escritor.

Desde nuestro punto de vista, el mayor símbolo que une un signo de la realidad con una postura ideológica mediante la animación, anida en aquellas escenas donde la oligarquía y la familia oficial del padre de Evita se convierten en cuervos. Los cuervos se tornan en lo fantasmagórico y metafórico dentro del film. Los cuervos son la oligarquía, los militares y la Iglesia. Todos ellos persiguen tanto a la niña Eva como al propio narrador Walsh. En este caso, el movimiento de la oligarquía o la familia oficial hacia el dibujo de los cuervos, se aplica a una vinculación fantasiosa que se carga de ideología, y que entonces plantea el ejercicio de la memoria también contaminado por la ideología. Asimismo, la escena que sintetiza lo que significó Eva para el pueblo es aquella que retoma a la Eva niña corriendo hacia el tren y huyendo de los cuervos. Esta escena es mostrada en varias instancias anticipando el desenlace al ir revelando una mano que se extiende. En la misma la focalización ya no se encuentra bajo la mirada del personaje Walsh, sino que se hace presente la mirada de Seoane. Ella mantiene el misterio hasta la escena final en la que podemos ver que esa mano pertenece a Evita ya mujer. Una vez más, la animación logra plantear simbólicamente que la representación de Eva siempre se vinculó al pueblo, es decir, a ella misma. En este sentido, queda claro que el film comprende que la historia política de Eva Perón nace a partir del suceso traumático de la muerte del padre y de su característica bastarda, y lo hace desde la propia memoria del personaje. En este film Eva Duarte muta en Eva Perón por el registro memorial de su bastardía.

Esta última escena que describimos en el párrafo anterior, nos hace pensar un nuevo tema de análisis que tiene que ver con la forma en que se construye a Eva Perón como heroína. El filme de Seoane recurre a dos variantes míticas que son la Eva-militante y la Eva-mártir; a su vez, refuta la variante de la Eva-mujer del látigo, humanizando el carácter y explicando el contexto histórico en que la 
heroína estuvo inmersa: — tiempos en que muchos empresarios solían acosar a las debutantes (...) donde a veces el poder se ejercía sobre los cuerpos más frágiles y el éxito no tenía que ver con dotes actorales. Pero ella quería ser actriz.

Esta presentación del personaje sigue la lógica de reconstruir su viaje de Junín a Buenos Aires, los logros en su carrera como actriz de radioteatro, la simpatía por Perón, su encuentro en el Luna Park, su historia de amor, su lucha política, su enfermedad, su muerte y la odisea de su cuerpo. Ese camino se emparenta con el propuesto por Joseph Campbell (la partida, la iniciación y el regreso) propiciando lo que Vogler explica como la identificación con el espectador, la cual se produce a partir de la narración y la vinculación del héroe con todos sus amigos y enemigos. Pero la manera de construir la enemistad -con la oligarquía y sus instituciones- o la amistad -con el pueblo y con Perón- es desde los elementos testimoniales, inclusive, desde contenidos alegóricos que son permitidos y justificados desde el propio registro de la animación. Así, además de los cuervos como el enemigo primordial, la animación permite otorgarle a Eva el don sobrenatural de sobrevolar las ciudades con hambre en España viendo niños esclavos, o asociar la furia hacia la oligarquía con el terremoto de San Juan.

Son diversos los momentos en los que el dibujo de un obrero representa la fidelidad y la lucha social. Este dibujo se trata del histórico obrero parado el 17 de octubre de 1945 en uno de los faroles de la Plaza de Mayo, pero aquí, ese obrero ferroviario se encuentra pintando un cuadro con tinta roja antes de ir a la Plaza. Ese obrero se postula como un amigo heroico de Eva Perón y se relaciona con la revolución peronista, al punto de hacerlo conectarse, ya en la Plaza trepado al farol, con una estatua femenina. Esta escena reproduce las pinturas: La creación de Adán de Miguel Ángel y La libertad guiando al pueblo de Eugene Delacroix. Y lo hace desde un intenso simbolismo, en tanto que el manto que cubre la estatua se colorea con la bandera argentina. En ese momento se acercan los dedos índices de ambos, del obrero y de quien hará referencia a Eva Perón. Entonces, ella es la creadora del obrero y es su libertaria. La imagen de Eva se compone así desde la vinculación entre el fanatismo revolucionario y la virtud jacobina, en tanto que — todos los obstáculos pueden ser desbaratados 
por la legitimidad moral-política que esta virtud reclama para sí (Sarlo, 2003, 240).

Así, el terror de la lucha es justificado si es acompañado por la virtud, es decir, el criterio de diferenciar al enemigo. En este sentido, el film se funda desde esta convención, entendiendo que sólo encarnando al fanatismo en ese obrero como representante de varios, se tendrá un criterio suficiente para mantenerlo como un argumento válido para una nueva identidad argentina, para una nueva composición del tejido social. Si bien hemos leído argumentaciones que apartan la vinculación de la postura jacobina de las acciones peronistas, podemos sostener que el film de Seoane estructura su relato entre amigos y enemigos y que, por ese mismo motivo es que se puede pensar la construcción de Eva como un personaje heroico.

En confluencia con ese fanatismo, Seoane labra una heroína melodramática que se entrega a su héroe, accionando por y para él. Son muchas las escenas donde los primeros planos sobre el dibujo de Eva denotan el amor hacia Perón y su lucha abnegada hacia el pueblo, al punto que se recomponen momentos cotidianos imposibles de comprobar en la historia por medio de documentos. Tal es así la escena donde discute con Perón para que se le otorgue la vicepresidencia, o la distancia del matrimonio a partir de su ardua tarea en la Fundación. Toda esta construcción de la heroicidad y de la abnegación, más allá de que tenga un contenido testimonial, muestra una brecha en la figura en tanto que, en términos de Deleuze, su imagen movimiento, su acción reacción muestra una sustracción, un costado que no vemos, un referente que se pierde.

Así, lo heroico en el filme, incluso desde lo testimonial -insistimos- levanta mitos que son rizomas, deltas, que establecen relecturas sobre la figura. Al igual que las pinturas mencionadas, hay otras intertextualidades que proponen un nuevo corrimiento. Por ejemplo: Rodolfo Walsh es el que narra su historia desde el cuento - Esa mujer escrito a partir de la entrevista a Moori Koenig. Otro punto importante es destacar cómo su voz se apropia en tercera persona de discursos provenientes del libro La razón de mi vida. La heroicidad descripta en ese libro a través de la primera persona, (recordemos que fue escrito por Penella 
de Silva y luego reescrito por Mendé según el Padre Hernán Benítez) se convierte en tercera persona y, de esta manera, se establece como un testimonio de época.

Un día -habría cumplido ya los siete años- visité la ciudad por vez primera. Llegando a ella descubrí que no era cuanto yo había imaginado. De entrada vi sus barrios de -miseria, y por sus calles y sus casas supe que en la ciudad también había pobres y que había ricos. (Perón, 2010, 13).

Entonces, las palabras de Eva dan cuenta de un espacio-tiempo que cambia en el film, ya que las mismas palabras dichas por Walsh refieren a su viaje a Buenos Aires pero siendo adolescente, en tanto que la animación la muestra llegando a la ciudad en su viaje definitivo.

Otro recurso donde confluye la creación de lo heroico de Eva Perón, son las sobreimpresiones. Eva viaja en su auto tocando las puertas de los sindicatos y los diputados para que liberen a Perón. Si bien este episodio es ficticio, Seoane coloca a Eva viajando en su auto, mirando los resultados de su acción. Así hay dos espacio-tiempo: el dibujo de Eva viajando y mirando, y la proyección del movimiento de masas del 17 de octubre de 1945 que se proyecta sobre las ventanillas del vehículo.

Estos ejemplos, logran demostrar que la memoria construye una imagen heroica, o decide memorizarla desde los mitos peronistas en una imagen heroica (Eva-santa, Eva-militante), estableciendo relecturas sobre el material de archivo y, tal como lo aclara Seoane, partiendo de la base de que se trata de una ficción animada con pinceladas de documental. En este sentido y acompañando la visión de Adolfo Burgos (2015), el cineasta que realiza una animación es honesto con su propia mirada sobre el tema a tratar y por este motivo deja en claro que está construyendo una representación de la realidad.

\section{Conclusiones}

A lo largo del artículo pusimos en disputa los conceptos de memoria e historia, para comprender como los mismos son reincorporados y utilizados dentro del 
cine de animación y el documental. Esta combinación nos llevó a conocer el concepto de documental animado que sería la categoría donde estaría inmersa la obra de María Seoane, Eva de la Argentina. Analizar específicamente este caso, nos despertó una serie de interrogantes. Nos preguntamos por el rol que desempeña una heroína como Eva Perón dentro del dispositivo de animación. La identificación que pudimos observar entre el dibujo y las imágenes de archivo nos hizo reflexionar sobre el constante corrimiento del referente. Éste muta en dibujo y resignifica desde ese mismo lugar los materiales históricos con los que trabaja el documental animado. A su vez revisando estudios como los de Burgos, Pinotti, Gionco, Bordwell, Lotman y Álvarez Sarrat nos preguntamos cómo la animación y sus procedimientos cuestionan el posicionamiento de la realidad dentro de la puesta en escena. En definitiva, allí se complejiza lo real de la representación. Concluimos que no existe en el dispositivo de animación una representación del objeto histórico en términos de imitación de la realidad, si no que existe una construcción de aquél siempre contaminado y explícitamente modificado por la creadora. Seoane, más allá de narrar la historia y proponer un registro memorial al respecto, termina por dar su juicio sobre ese fragmento histórico en el que se desempeñó Eva Perón. El dispositivo documental animado de ese modo establece una lectura desde el presente sobre los hechos históricos, y por sus características aumenta la función poética de los archivos, y por supuesto de la historia narrada mediante dibujos. Desde allí genera mitos, tanto en sentido amplio (es decir entendiendo como mito toda construcción discursiva) como también en el sentido más específico, donde el mito recurre a la construcción de un héroe con su camino predeterminado por un destino. En este caso un destino animado que viene a reflexionar sobre el pasado -el del peronismo y el de los años '70- como también a repensar el presente, proporcionando una construcción memorial.

\section{Referencias bibliográficas}

Álvarez Sarrat, S. (2011) Animación, el medio contaminado. Dibujo, pintura y cine. En C. Garzón. Señas de identidad. Reflexiones sobre el arte de la animación. Actas del 1er Foro Académico sobre Animación. V Festival Internacional de Animación de Córdoba, ANIMA ’09. Córdoba: Eduvim. 
Aprea, G. (2015). Documental, testimonios y memorias. Miradas sobre el pasado militante. Buenos Aires: Manantial.

Barthes, R. (1980). Mitologías. Buenos Aires: Siglo XXI.

Bordwell, D. (1993). El arte cinematográfico. Barcelona: Paidós.

Burgos, A. (2015) Ficciones constructoras de realidad. El cine de animación documental, [Tesis doctoral] Universidad de Murcia. Facultad de Bellas Artes.

Cangi, A. (2007). El rostro en el documental como drama político. En Rival, S. \& J. Sartora. Imágenes de lo real. La representación de lo político en el documental argentino. Buenos Aires: Libraría.

De Grandis, R. (2006). Reciclaje cultural y memoria revolucionaria. La práctica polémica de José Pablo Feinmann. Buenos Aires: Biblos.

Gionco, P. (2013). "La animación como discurso de lo real", ponencia presentada en el III Congreso Internacional Artes en cruce. En https://docs.google.com/file/d/oB3Xnk4AAbwY_T1hnVFh1Tko3cm8/e dit

Lotman, I. (2000), Sobre el lenguaje de los dibujos animados. La semiósfera: semiótica de las artes y la cultura, t. III. Madrid: Cátedra.

Nichols, B. (1997). La representación de la realidad. Cuestiones y conceptos sobre el documental. Barcelona: Paidós.

Piedras, P. (2014). El cine documental en primera persona. Buenos Aires: Paidós.

Pinotti, L. (2015). La animación no ficcional Un análisis sobre la construcción del sentido en el documental animado Vals con Bashir. Cine Documental, No 12, ISSN 1852-4699. Disponible en: http://www.cinedocumental.com.ar/revista/pdf/12/12-Art6.pdf

Sarlo, B. (2003). La pasión y la excepción. Buenos Aires: Siglo XXI.

Vogler, C. (2002). El viaje del escritor. Barcelona: Robinbook.

White, H. (1992) Metahistoria. La imaginación histórica en la Europa del siglo $X I X$. México: FCE.

Cómo citar: Trombettta, J.C. (2017). "El lenguaje de animación como herramienta poética para mitificar la historia de Eva Perón”. Fotocinema. Revista científica de cine y fotografia, $\mathrm{n}^{0}$ 14, pp. 365-xx. Disponible: http://www.revistafotocinema.com/ 